\title{
The correlations among learning motivation, self-confidence, and writing ability of students descriptive text
}

\author{
Dean May Julian ${ }^{1}$, Baginda Simaibang ${ }^{2}$, Mulyadi Mulyadi ${ }^{2}$ \\ ${ }^{1}$ Sekolah Menengah Pertama Negeri 1 Lubai Ulu Muaraenim, Indonesia \\ ${ }^{2}$ Universitas PGRI Palembang, Indonesia
}

\begin{tabular}{l} 
Article Info \\
\hline Article history: \\
Received Jul $8^{\text {th }}, 2021$ \\
Revised Aug $13^{\text {th }}, 2021$ \\
Accepted Aug $30^{\text {th }}, 2021$ \\
\hline
\end{tabular}

\section{Keyword:}

Learning motivation

Self-confidence

Writing ability

\begin{abstract}
This thesis was concerned with the inquiry on the correlations among learning motivation, self-confidence, and writing ability of the seventh grade students at State Junior High School of Lubai Ulu Sub-District of Muaraenim Regency. The problem of the study was to investigate the correlation among students' learning motivation, self-confidence, and writing ability. The total number of the population were 474 students. The sample for this study was 83 students taken through a simple random sampling technique. Data were collected by adopting a questionnaire for learning motivation, self-confidence, and test for writing ability. Data were analyzed by using r-Product Moment and Multiple Regression. Finding showed that: (1) there was significant correlation between learning motivation and writing ability; (2) there was not any significant correlation between self-confidence and writing ability; (3) there was not any significant correlation between learning motivation and self-confidence; (4) there were significant correlations among learning motivation, self-confidence, and writing ability of seventh grade-students at state Junior High School of Lubai Ulu Muaraenim.
\end{abstract}

(C) 2021 The Authors. Published by IICET.

This is an open access article under the CC BY-NC-SA license

(https://creativecommons.org/licenses/by-nc-sa/4.0

\section{Corresponding Author:}

Julian, D. M.,

Sekolah Menengah Pertama Negeri 1 Lubai Ulu Muaraenim, Indonesia

Email: d34nmj@gmail.com

\section{Introduction}

Writing is one of the language skills among the four language skills that illustrates how a foreign language learner exercises his or her linguistic competence. An English learner's writing output may represent the learner's expertise through the written discourse they present in English language patterns. However, it is not always easy for a foreign language learner to write, particularly in any other language instead of the first language, because of several factors.

One of the essential aspects of writing is motivation. It would be difficult for students to do writing tasks without good encouragement. Theoretically, motivation strengthens any person's inner strength to do something. So, motivation to write is an inner force that decides effective operation of writing. The students need written encouragement, so they will be involved in writing activities with motivation. Even though several concerns such as grammar, diction, pronunciation, vocabulary, and punctuation will be found. The students are able to build a successful composition by writing. It demonstrates that motivation is needed in writing by students [1]. Based on the facts and problems, the writer assumes that if the students are not highly motivated, the English writing activity will not be successful. 
Another issue faced in writing by students is the complexity of developing a concept into a paragraph and following the text's guidelines. [2] claimed that another difficulty in writing is not only the generation and composition of ideas, but also the presentation of ideas in the text. Writing is also a way of producing language that comes from our thinking. Students may express their thoughts, ideas and everything that happens in their minds by writing. These variables will cause students to think they can't do it. They don't believe in their competence. For students to start learning English, particularly writing, this personality can be the main problem.

Based on a preliminary interview with one of the English teachers at State Junior High School 1 of Lubai Ulu, Muaraenim, it was found that some of the problems faced by the students were: (1) the students were afraid of making mistakes or errors, (2) they found it difficult to produce grammatically correct sentences and use vocabulary varieties to express their vocabulary varieties. These can hamper learning processes in writing teaching. In addition, the results of the writing performance of the students were not as high as the results of the other English language skills, where their average score was 55 below the minimum criteria of mastery learning.

Some studies have been carried out dealing with the correlations among learning motivation, selfconfidence and writing ability. [3] observed that task-oriented technical writing tasks were found to have a positive impact of a substantial increase in self-confidence, an overall improvement in communication skills, a decrease in the capacity to be manipulated by others, improved analytical skills, and increased control over life conditions. On the contrary, [4] in his research that there was no meaningful correlation between selfconfidence and the achievement of paragraph writing.

Considering the issues above, the author was inspired to conduct a study on the correlations among learning motivation, self-confidence, and writing ability in descriptive text of seventh-grade students at Lubai Ulu sub-district of Muaraenim regency state junior high schools.

\section{Method}

This study was a quantitative research. In this study, the writer used correlational research method to find out the relationship between students' learning motivation, self-confidence, and writing ability. Correlation design is quantitative testing techniques in which investigators calculate the degree of association (relationship) between two or more variables by using the correlation analysis statistical method [5].

This study consisted of three variables; they were learning motivation, self-confidence, and writing ability. The population of this study was all the seventh-grade students of state Junior High School of Lubai Ulu Sub district of Muaraenim in the academic year of 2020/2021. In measuring the number of sample in this study, the writer used Slovin formula. The sampling technique used in this study was purposive sampling; it is the use particular aim of the analysis and personal judgement to pick the sample [6]. The criteria of the school to be the sample in this study were as follows: 1) the school were on the same level of accreditation; 2) the writer could get access to do the research at the school; and 3) the school was still open during this pandemic covid 19. Based on the criteria mentioned, two state junior high schools were stated as the sample of the study. They were State Junior High School 1 and State Junior High School 3 of Lubai Ulu Muara Enim in the academic year of 2020/2021. Data were collected by adopting a questionnaire for learning motivation, self-confidence, and test for writing ability. Data were analyzed by using r-Product Moment and Multiple Regression Analysis.

\section{Results and Discussions}

In this study, normality test was done by using Kolmogorov Smirnov and calculated by applying SPSS. The significant score of writing ability was 0.182 , learning motivation was 0.055 , and self confidence was 0.076 . The significant scores were higher than 0.05 . Therefore, the data used in this study were normal.

The homogeneity check was carried out by using the Levene Statistics for Windows software in SPSS 21. The significant value of Levene Statistic was 0.254 . This value was above 0.05 . Therefore, the data used in this study were homogenous.

The result of linearity test shows the significant value of Deviation from Linearity between writing ability and learning motivation was 0.427 higher than 0.05 ; it means that two variables (writing ability and learning motivation) had a linear correlation. The result of significant value of linearity test Deviation from Linearity was 0.797 higher than 0.05 ; it means that two variables (writing ability and self confidence) had a linear correlation. 


\section{Correlations between learning motivation and writing ability of the seventh grade students at state Junior} High School of Lubai Ulu sub-district of Muara Enim regency (Research Problem Number 1)

The first hypothesis was tested as follows:

Ho : There was not any significant correlation between learning motivation and writing ability of the seventh grade students at state Junior High School of Lubai Ulu sub-district of Muara Enim regency.

$\mathrm{Ha}: \quad$ There was a significant correlation between learning motivation and writing ability of the seventh grade students at state Junior High School of Lubai Ulu sub-district of Muara Enim regency.

In order to answer the first research questions, the result of learning motivation questionnaire and writing ability through Pearson Product Moment correlation can be seen in Table 1.

Table $1<$ Correlations between Learning Motivation and Writing Ability>

\begin{tabular}{lcc}
\hline Correlation & Pearson Correlation & Sig. (2-tailed) \\
Writing ability - Learning & $.864^{* *}$ & .000 \\
Motivation & .40 \\
\hline
\end{tabular}

For the contribution of self confidence and writing ability can be seen in Table 2.

Table $2<$ Model Summary>

\begin{tabular}{lccc}
\hline $\mathrm{R}$ & R Square & Adjusted R Square & Std. Error of the Estimate \\
$.864^{\mathrm{a}}$ & .747 & .744 & .91641 \\
\hline
\end{tabular}

Table 2 shows that p-value is 0.000 . This was lower than 0.05. It was significant. So, Ha was accepted while Ho was rejected. Therefore, there was significant correlation between the students' learning motivation and writing ability of the seventh grade students at state Junior High School of Lubai Ulu sub-district of Muara Enim regency.Table 2, the result of coefficient correlation between learning motivation and writing ability was $\mathrm{R}_{\mathrm{y} \times 2}=0.054$, with $\mathrm{r}^{2}=0.003(0.3 \%)$.

Based on the result of the study, it was found that there was positive and significant correlation between the students' learning motivation and writing ability of the seventh grade students at state Junior High School of Lubai Ulu sub-district of Muara Enim regency. If we interpret it based on the table of the Strength of Correlation Coefficient, it can be inferred that there was a strong correlation between learning motivation and writing ability of the seventh grade students at state Junior High School of Lubai Ulu sub-district of Muara Enim regency. The learning motivation influence the students' writing ability of the seventh grade students at state Junior High School of Lubai Ulu sub-district of Muara Enim regency in the academic year 2020/2021. It means that when the students have high self-confidence, they will have a high writing ability.

The result of the study showed that learning motivation was one of important aspects in writing. Without a strong motivation, students would be difficult to do writing activity. Theoretically, motivation is all of inner power reinforcing any person to do something. So, learning motivation is an inner power that determines successful writing activity. The students need motivation in writing, because with motivation they will active to do writing activity. Even though they will find many problems such as grammar, diction, spelling, vocabulary and punctuation. In writing, the students are able to make a good composition. It proves that motivation needed by students in writing.

The result of this study was in line with the result of [1] study. In her stated that students need written motivation and they are inspired to do writing tasks with motivation. Even though several concerns such as grammar, diction, pronunciation, vocabulary, and punctuation will be found. The students are able to build a successful composition by writing. It shows that students need encouragement to write.

The result of this study supports some previous studies such that of conducted [3]. The results showed that the research found out the level of the correlation between the students' motivation and the writing ability among the eleventh grade students of Senior High School Utama Wacana Metro in the academic year of $2009 / 2010$ was $25,60 \%$. It can be proved that there was positive and significant correlation between the students' motivation and the writing ability among the eleventh grade students of Senior High School Utama Wacana Metro in the academic year of 2009/2010.

The result of this research showed that learning motivation is one of some variables influencing the students' ability in learning language. English language learning is influenced by motivation. To emphasize its effects on students' learning, Crookes and Schmidt as cited in [7], indicated that at schools, motivation is important because of its strong impact on the learning of students, because motivation is a key to the learning 
achievements of students. Thus, students with a good motivation to learn often study better than those with little or no motivation to learn. Gardner and Lambert, as cited in [7] mentioned that motivation can be said to be an important element in determining the achievement of learning by students, in which motivation overrides the capacity that accounts for a large proportion of individual variability in language variability in the achievement of language learning.

The correlation coefficient of $\mathrm{r}=0.864$ was observed between learning motivation and writing ability, then the coefficient of determination is $\mathrm{r}^{2}=0.747$. This means that $74.7 \%$ of the total variation in writing ability can be explained or accounted for by variation in learning motivation.

This means that the student which have higher that learning motivation have the higher writing ability outcomes. It means there was a positive correlation between students' learning motivation and their writing ability at the seventh grade students of state Junior High School of Lubai Ulu sub-district of Muara Enim regency in academic year 2020/2021.

Correlations between Self Confidence and Writing Ability of the seventh grade students at state Junior High School of Lubai Ulu sub-district of Muara Enim regency (Research Problem Number 2)

The second hypothesis was tested as follows:

Ho : $\quad$ There was not any significant correlation between self Confidence and writing ability of the seventh grade students at state Junior High School of Lubai Ulu sub-district of Muara Enim regency.

$\mathrm{Ha}$ : There was a significant correlation between self Confidence and writing ability of the seventh grade students at state Junior High School of Lubai Ulu sub-district of Muara Enim regency.

In order to answer the second research questions, the result of self confidence questionnaire and writng ability through Pearson Product Moment correlation can be seen in Table 3.

Table $3<$ Correlations between Self Confidence and Writing Ability>

\begin{tabular}{lcc}
\hline Correlation & Pearson Correlation & Sig. (2-tailed) \\
Writing ability - Self & .054 & .630 \\
confidence & .054 \\
\hline
\end{tabular}

For the contribution of self confidence and writing ability can be seen in Table 4.

Table $4<$ Model Summary $>$

\begin{tabular}{lccc}
\hline $\mathrm{R}$ & $\mathrm{R}$ Square & Adjusted R Square & Std. Error of the Estimate \\
$.054^{\mathrm{a}}$ & .003 & -.009 & 1.81995 \\
\hline
\end{tabular}

Table 3 shows that p-value is 0.630 . This was higher than 0.05 . It is not significant. So, Ho was accepted while $\mathrm{Ha}$ was rejected. It means that there was not any significant correlation between self confidence and writing ability of the seventh grade students at state Junior High School of Lubai Ulu sub-district of Muara Enim regency. Table 4, the result of coefficient correlation between self confidence and writing ability was $\mathrm{R}_{\mathrm{y} \times 2}=0.054$, with $\mathrm{r}^{2}=0.003(0.3 \%)$

The result of the study showed that there was not any significant correlation between self confidence and writing ability of the seventh grade students at state Junior High School of Lubai Ulu sub-district of Muara Enim regency. If we interpret it based on the table of the Strength of Correlation Coefficient, it can be inferred that there was very weak correlation between confidence and writing ability of the seventh grade students at state Junior High School of Lubai Ulu sub-district of Muara Enim regency.

The correlation coefficient of $r=0.054$ was observed between self confidence and writing ability, then the coefficient of determination was $\mathrm{r}^{2}=0.003$. This means that only $0.3 \%$ of the total variation in writing ability could be explained or accounted for by variation in self confidence.

This study is in line with the study conducted by [4] his research argued that there was no significant correlation between self-confidence and paragraph writing achievement. On the contrary, this study did not support the study of [3] who found that there was significant influence of students' self-confidence on their essay writing achievement. 


\section{Correlations between Learning Motivation and Self Confidence of the seventh grade students at state} Junior High School of Lubai Ulu sub-district of Muara Enim regency (Research Problem Number 3)

The third hypothesis was tested as follows:

Ho : There was not any significant correlation between Learning Motivation and Self Confidence of the seventh grade students at state Junior High School of Lubai Ulu sub-district of Muara Enim regency.

$\mathrm{Ha}: \quad$ There was a significant correlation between Learning Motivation and Self Confidence of the seventh grade students at state Junior High School of Lubai Ulu sub-district of Muara Enim regency.

In order to answer the third research questions, the result of Learning Motivation and Self Confidence questionnaire through Pearson Product Moment correlation can be seen in Table 5.

Table 5 shows that $p$-value is 0.117 . This is higher than 0.05 . It is not significant. So, Ho was accepted while Ha was rejected. Therefore, there was not any significant correlation between Learning Motivation and Self Confidence of the seventh grade students at state Junior High School of Lubai Ulu sub-district of Muara Enim regency.

Table 5 <Correlations between Learning Motivation and Self Confidence>

\begin{tabular}{lcc}
\hline Correlation & Pearson Correlation & Sig. (2-tailed) \\
\hline $\begin{array}{l}\text { Self confidence- Learning } \\
\text { Motivation }\end{array}$ & .173 & .117 \\
\hline
\end{tabular}

For the contribution of learning motivation to self confidence can be seen in Table 6 .

Table $6<$ Model Summary

\begin{tabular}{lccc}
\hline $\mathrm{R}$ & $\mathrm{R}$ Square & Adjusted R Square & Std. Error of the Estimate \\
\hline $.173^{\mathrm{a}}$ & .030 & .018 & 3.384 \\
\hline
\end{tabular}

Table 6 , the result of coefficient correlation between learning motivation and self confidence is Ryx $2=$ 0.173 , with $\mathrm{r} 2=0.030(3 \%)$. The result of the study showed that there was not any significant correlation between learning motivation and self confidence of the seventh grade students at state Junior High School of Lubai Ulu sub-district of Muara Enim regency. If we interpret it based on the table of the Strength of Correlation Coefficient, it can be inferred that there was very weak correlation between seventh grade students at state Junior High School of Lubai Ulu sub-district of Muara Enim regency.

The coefficient of determination can be used to more fully interpret $\mathrm{r}$ and is obtained by simply squaring the correlation coefficient $r\left(r^{2}\right)$. The coefficient of determination is defined as the percent of the variation in the values of the dependent variable (y) that can be "explained" by variations in the value of the independent variable (x) This technique results in a percent value which makes it easier to interpret more precisely. Thus, if a correlation coefficient of $r=0.173$ was observed between variable $\mathrm{x}$ (learning motivation) and variable y (self confidence), then the coefficient of determination is $\mathrm{r}^{2}=0.03$. This means that only $3 \%$ of the total variation in variable y (learning motivation) can be explained or accounted for by variation in variable $\mathrm{x}$ (self confidence). Therefore, it can be seen that only $3 \%$ of the total variation of learning motivation can be explained by variation in self confidence.

Correlations among learning motivation, self confidence and writing ability of the seventh grade students at state Junior High School of Lubai Ulu sub-district of Muara Enim regency (Research Problem Number 4).

The fourth hypothesis was tested as follows:

Ho : There was not any significant correlation between learning motivation, self confidence, and writing ability of the seventh grade students at state Junior High School of Lubai Ulu sub-district of Muara Enim regency.

$\mathrm{Ha}: \quad$ There was a significant correlation between learning motivation, self confidence, and writing ability of the seventh grade students at state Junior High School of Lubai Ulu sub-district of Muara Enim regency.

In order to answer the fourth research question, the writer analyzed the correlation among the learning motivation, self confidence and writing ability by using analysis of multiple linier regression technique through $\mathrm{F}$-test. In this $\mathrm{F}$ test, $\mathrm{F}_{\text {count }}$ is determined which is then compared with the $\mathrm{F}_{\text {table }}$ value. 
$\mathrm{H}_{\mathrm{a}}: \rho>0$

$\mathrm{H}_{0}: \rho=0$

Reject $\mathrm{H}_{0}$ and Accept $\mathrm{H}_{\mathrm{a}}$ if $\mathrm{F}_{\text {count }}>\mathrm{F}_{\text {table }}$

The critic value of $F_{\text {table }}$ known was 3.96. It is used as the standard of $F_{\text {table }}$ which will then be compared with $F_{\text {count }}$. The method to know the critic value of $F_{\text {table }}$ is by using the degree freedom $=n-2(d f=83-2)$ formula with a significant level of $5 \%$ or equal to 0.05 .

Table 7 <Correlations among Learning Motivation, Self Confidence and Writing Ability>

\begin{tabular}{llcl}
\hline Model & & F & Sig. \\
\hline 1 & Regression & 124.431 & $.000^{\mathrm{b}}$ \\
\hline
\end{tabular}

Table $8<$ Strength of Correlations among Learning Motivation, Self Confidence and Writing Ability

Model Summary>

\begin{tabular}{cccc}
\hline $\mathrm{R}$ & $\mathrm{R}$ Square & Adjusted R Square & Std. Error of the Estimate \\
\hline $.870^{\mathrm{a}}$ & .757 & .751 & .905 \\
\hline
\end{tabular}

Table 4.7 shows that $\mathrm{p}$ - value is 0.000 . It was lower than 0.05 . So, Ha was accepted while H0 was rejected. Therefore there were significant correlations among learning motivation, self confidence and writing ability of the seventh grade students at state Junior High School of Lubai Ulu sub-district of Muara Enim regency. Table 4.8 , the result of coefficient correlation among learning motivation, self confidence and writing was Ryx $2=$ 0.870 , with $\mathrm{r} 2=0.757(75.7 \%)$.

The result of the study showed that there were positive and significant correlation among learning motivation, self confidence and writing ability of the seventh grade students at state Junior High School of Lubai Ulu sub-district of Muara Enim regency.[8] stated that if the coefficient is a positive number, the variables are directly related (i.e., as the value of one variable goes up, the value of the other also tends to do so). If, on the other hand, the coefficient is a negative number, the variables are inversely related (i.e., as the value of one variable goes up, the value of the other tends to go down). The coefficient correlation of learning motivation, self confidence and writing ability was positive; 0.870 , means that there were positive correlation among learning motivation, self confidence and writing ability. An increase of learning motivation and self confidence variables would correspond to an increase of writing ability variable, thus implying a direct relationship among the variables.

Descriptive statistic result showed that the most dominant indicators of learning motivation is teacher encourages students to learn English, such as: teacher gives reward to students; teacher becomes an inspiration; and teacher uses interesting method in teaching with average score was 3.8. The most dominant indicators of self confidence is autonomous with average score was 4.8. Autonomous is the independence to make decision without any intervention from other. While, The most dominant indicators of writing ability is content, that is related to topic and details of students' writing, with average score was 3.05.

The correlation coefficient of $r=0.870$ was observed between learning motivation, self confidence, and writing ability, then the coefficient of determination was $\mathrm{r}^{2}=0.757$. This means that $75.7 \%$ of the total variation in writing ability can be explained or accounted for by variation in learning motivation and self confidence. If we interpret it based on the table of the Strength of Correlation Coefficient, it can be inferred that there was a strong correlation among learning motivation, self confidence and writing ability of the seventh grade students at state Junior High School of Lubai Ulu sub-district of Muara Enim regency.

Several studies also revealed that learning motivation and self confidence influence writing ability. [1] research found the correlation between the students' motivation and the writing ability among the eleventh grade students of Senior High School Utama Wacana Metro. The result of [3] study showed that there was a significant correlation between students' self-confidence and their essay writing achievement.

Students with high trust can appreciate and use the opportunity to demonstrate their skill in writing sessions well. It can improve their performance by loving the class and conducting the writing confidently. In such situations, it is important to develop the self-confidence of learners. As the facilitator of the teaching process, the teacher should be able to play the position. That's why students need to develop their selfconfidence to be involved in writing in English. [9] stated that self-confidence is the belief in oneself and in skills. It can refer to how individuals feel about themselves and their skills. Each person has distinct levels of self-confidence. Experience and life condition take part on someone's self-confidence growth. It is connected with each individual's psychological experience. Shyness, communication problems, social anxiety and lack of 
assertiveness may result from having low trust. In contrast to learners with low self-confidence, students with high self-confidence have motivation and purpose. In writing, highly optimistic students will be more involved and more excited about receiving the material. It will facilitate the learning process of teaching.

The result of the study proved that there were positive and significant correlation among learning motivation, self confidence and writing ability of the seventh grade students at state Junior High School of Lubai Ulu sub-district of Muara Enim regency. It means that students' learning motivation and self-confidence give dominant effect on writing ability of the seventh grade students at state Junior High School of Lubai Ulu sub-district of Muara Enim regency

\section{Conclusions}

In line with the results and discussions in the previous chapter, some conclusions could be presented as follows. 1) There was significant correlation between learning motivation and writing ability of seventh gradestudents at state Junior High School of Lubai Ulu Muaraenim. 2) There was not any significant correlation between self-confidence and writing ability of seventh grade-students at state Junior High School of Lubai Ulu Muaraenim. 3) There was not any significant correlation between learning motivation and self-confidence of seventh grade-students at state Junior High School of Lubai Ulu Muaraenim. 4) There were significant correlations among learning motivation, self-confidence, and writing ability of seventh grade-students at state Junior High School of Lubai Ulu Muaraenim.

\section{References}

Aryanika, S. 2016. The correlation between the students' writing motivation and the writing ability. English Education: Jurnal Tadris Bahasa Inggris, .9(1), 215-232.

Creswell, J. W. 2012. Educational research: Planning, conducting and evaluating quantitative and qualitative research (4th ed.). Boston, MA: Pearson Education, Inc.

Fraenkel, Jack R., Wallen, Norman, \& Hyun, H. . 2012. How to design and evaluate research in education - 8th ed.,NY: McGraw-Hill, Inc

Goleman, D. 2007. Social intelligence. Random house.

Juita, T., Anastasya, F., \& Taridi, 2019. The correlation between students'writing motivation and writing ability of Islamic Senior High School As'ad Jambi (Doctoral dissertation, UIN Sulthan Thaha Saifuddin Jambi).

Mardiansyah, R.. 2018. A Correlation between Self-Confidence and Essay Writing Achievement. Edukasi: Jurnal Pendidikan dan Pengajaran, 5(2), 154-166.

Mukaka, M. M.. , 2012. Statistics corner: a guide to appropriate use of correlation in medical research. Malawi Medical Journal24(3), 69-71

Richards, J. C., \& Renandya, W. A. 2002. Methodology in language teaching.1/2. An anthology of current practice. New York: Cambridge University Press.

Tuan, L. T. 2012. An Empirical Research into EFL Learners' Motivation. Theory \& Practice in Language Studies, 2(3).

Zikrullah. 2017. The correlation between self-confidence and paragraph writing achievement of English Education Study Program Students, (Undergraduate's thesis). Sriwijaya University, Palembang, Indonesia. 